\title{
Effectiveness of Motivational Interviewing (MI) Technique Towards Resilience of Sexual Violence Students of Yunior High School in Nganjuk
}

\author{
Esty Rokhyani \\ ${ }^{1}$ Corresponding author, Education Authorities in Nganjuk \\ Dermojoyo Street No.19 Nganjuk Jatim, Indonesia \\ Samsudi \\ ${ }^{3}$ Doctoral Program, State University of Semarang \\ Kampus Sekaran Gunungpati Semarang, Indonesia
}

\author{
Sugiyo \\ ${ }^{2}$ Doctoral Program, State University of Semarang \\ Kampus Sekaran Gunungpati Semarang, Indonesia \\ Edy Purwanto \\ ${ }^{4}$ Doctoral Program State Univesity of Semarang \\ Kampus Sekaran Gunungpati Semarang, Indonesia
}

\begin{abstract}
The purpose research eere to determine a resilience's level of students who were victims of sexual violence, to determine Motivational interviewing technique incresed the student's resilience victims and the effectiveness of the Motivational interviewing technique in increasing the resilience of students who were victims of sexual violence in junior high schools in Nganjuk. This method was quasy experimental by the Pretest-Posttest Control Group Design experimental design. Data analysis method uses paired t test sample and $\mathbf{N}$ gain test. The results showed that the level of resilience of victims of junior high school sexual violence in Nganjuk was illustrated before treatment was carried out, so the resilience of victims of sexual violence was largely low. After giving treatment in the form of Treatment with Motivational Interviewing Techniques increased to a high category. Motivational interviewing techniques can increase the resilience of victims of junior high school sexual violence in Nganjuk. The Motivational interviewing techniques had increased students's resilience who are victims of high school sexual violence in Nganjuk. Improvement's significant was seen from the paired sample $t$ test results so that hypotesis was accepted. Also supported by the results of the $\mathrm{N}$-gain test which states that the MI technique increased resilience of students in junior high schools in Nganjuk.
\end{abstract}

Keywords:- Motivational interviewing, resilience, victims of violence and sexual abuse.

\section{INTRODUCTION}

The trauma caused by students due to the occurrence of sexual violence experienced (adversity), there are students who are able to survive and recover from adversity that has ever experienced, but there are also students who fail because they did not manage to get out of an unfavorable situation. The ability to continue life after being hit by adversity or survive in an environment with heavy pressure is not a fortune, it shows the existence of certain abilities in individuals known as resilience (Tugade and Frederikson, 2004: 4).

Randal (2010) states that the sexual violence experienced by one family member is a stressor event that is quite heavy for the family. This will have an impact and trauma on other family members. To deal with these conditions each family member must have resilience in order to be able to rise and adapt to the crisis that occurred. Resilience is a capacity that is universal and with that capacity, individuals, groups, or communities are able to prevent, minimize, or fight the effects that can damage when they experience disaster or misfortune (Grotberg, 1995).

Bonanno (2004) define resilience as an individual's ability to maintain healthy and stable physical and mental conditions, and be able to gain positive experiences and emotions even in difficult situations. Songprakun (2009) conducted research on efforts to increase religiosity by the method of biblocounseling. This finding provides evidence that bibliocounseling supports the use of biblocounseling in increasing the resilience of individuals with middle depression in Thailand. Dewi (2014) found that home room program technical group guidance services had an effect on increasing the resilience of aviation vocational students, which was shown by children after answering post-test questions was higher than answering pre-test questions. The resilience of victims of sexual violence to junior high school students needs to be increased with the assistance of teachers in schools, especially counseling guidance teachers.

Psychological effects of students who experience trauma from sexual violence greatly affect the level of resilience. Child sexual abuse has different traumatic effects on a person and can be very worrying because it can have long-term effects throughout a child's life. Santrock (2004) found that the greatest impact that will continue into his adult life is fear and low self-esteem. Whitffen and MacIntosh (2005) found that experiences of sexual violence 
in childhood are related to emotional stress in adulthood and difficulty in having intimate relationships as adults.

The impact of the violence experienced can be seen from the aspect of resilience. Based on the subject, the child feels disliked by those around him, feels worthless, feels nobody loves, is not confident, but is still convinced that everything will end well. This hope can certainly be a capital for the subject to survive and be based in his work. MI is a student-centered for increased intrinsic motivation for exploring change to resolved ambivalence (Milller, 2005). Wagner and Ingersoll (2008) explain that Motivational interviewing (MI) is a technique in cognitive and behavior, as a means to positively resolve tensions created by students who are unresolved about various problems. Acoording Miller and Rollnick, (2002), MI can be conceptualized as emotional therapy. MI has proven effective in promoting behavior change through nonjudgmental approaches and communication styles that are able to increase competence, autonomy, and intrinsic motivation for students

This study raised the MI method in increasing student resilience victims of sexual violence. MI is generally performed for the treatment of patients in psychological treatment, while this study emphasizes the use of methods. Previous research that used techniques to increase resilience included biblocounseling, home room program techniques, peer counseling to deal with traumas of violence that had been received. While this study uses MI techniques adopted from the research of Dunn et al. (2001); Hettema et.al (2005); Miller, (2005), Miller and Rollnick, (2012). The aim of study were determine the effectiveness of MI techniques increased the Student's resilience of junior high school sexual violence in Nganjuk.

\section{LITERATURE REVIEW}

\section{$>$ Motivational Interviewing (MI)}

$\mathrm{MI}$ is a technique derived from a humanisticphenomenological approach in order to motivate clients to towards agreed development changes (Erford, 2017: 176). Naar King and Suarez in (Erford, 2017: 198) states that MI is a subtle and respectful method for communicating to someone about a change that is experienced that is difficult to be done in a healthier way and in line with the goals and values to maximize human potential.

Miller and Rollnick (2012), Motivational interviewing (MI) or which means motivational interviewing is an intervention that focuses on exploration, resolves two contradictory things and centers on the motivation process in an individual. The IQ is more focused on how the client can have motivation to create change. As Miller said at the MINT forum discussion at the end of December 2008 explained that, MI is a form of client-focused collaboration that guides to obtain and strengthen the desire to make changes (Soderlund, 2010: 8). There are four MI principles identified by Miller and Rollnick in (Erford, 2017: 199)

\section{- Express empathy}

To conduct a counseling session, a counselor expresses empathy, warmth, sincerity and unconditional positive assumptions, thus building a strong therapeutic relationship.

\section{- Develop discrepancies}

The counselor helps the client to tell and describe various thoughts, feelings and conflicts so that the client is aware of the mismatch between the wishes of the client and the events experienced by the client. Rollnick (2012) proposes that counselors use a set of skills called OARS (Open-ended questions, Affirmation, Reflecting skills and Summaries). Open-ended questions are that using openended questions will provide a lot of data obtained from clients. Affirmation as an affirmation, the counselor conveys the values of what is conveyed by the client and helps recognize his inner strength and resources. Reflecting skills, the counselor expresses sympathy, expresses fundamental feelings, the meaning of what the client conveys, highlights important things so that the client feel himself understood. Summaries are summaries used to review what the client is saying to move towards change.

\section{- Receive resistance}

Resistance is also referred to as the result or counselor and client.

\section{- Supports self-efficacy}

Counselors encourage and support clients to believe in changing their lives.

\section{$>$ Resilience}

Resilience was a ability for solving a problems, survive, overcome stress and develop amidst life's difficulties (Connor and Davidson, 2003). Resilience is related to the ability of individuals to realize individual qualities that can develop amid difficulties (Connor and Davidson, 2003). Reivich and Shatte (2002) deal with and respond to problems or trauma in a productive and healthy way that affects stress in living everyday life. Wagnild and Young (1993; in Resnick et al 2011: 2) defines resilience as differences, characteristics, and the ability of individuals to successfully overcome change and disadvantage successfully.

Resilience be able to adapt a problems, survive, overcome stress and develop amidst life's difficulties (Connor and Davidson, 2003). Resilience is related to the ability of individuals to realize individual qualities that can develop amid difficulties (Connor and Davidson, 2003).Reivich and Shatte (2002) said resilience a ability to deal with and respond to problems or trauma in a productive and healthy way that affects stress in living everyday life. Wagnild and Young (1993; in Resnick et al 2011: 2) defines resilience as differences, characteristics, and the ability of individuals to successfully overcome change and disadvantage successfully. Peters et al (2005: 13) explain that resilience refers to positive adaptation patterns that occur in the present. 
Connor and Davidson (2003) consists of five aspects, the following are aspects of Personal competence, high standards, and tenacity are factors that support a person to move forward towards a goal when the person is experiencing pressure or adversity. Personal competence, high standards, and tenacity is the ability and competence of himself to do something, achieve a goal, and in dealing with obstacles that occur, as well as manage and implement an action needed in order to achieve business results. Trust in one's instances, tolerance of negative affect, and stressing effects of stress focuses on calmness, decision, and accuracy when dealing with stress. Positive Acceptance of Change and Secure Relationships with Others, adaptability is related to adaptation and good relations with other people owned by individuals. Positive Acceptance of Change and Secure Realities with Others, adaptability is related to the ability to adapt or be able to adapt when faced with change. Emotional And Cognitive Control Under Pressure, Ability To Access Assistance From Others Social Support / Self Control focuses on achieving goals and the ability to get help from others or social support and Spiritual Influences Meaning is one's belief in God or fate. Where individuals depend themselves on God and fate that has been outlined.

Wagner and McMahon (2004) explained that Motivational interviewing (MI) is one of the counseling techniques. Apodaca and Longabaugh (2009) show that the results of the MI method give three changes including the students changing the speech intention (related to better results); student experiences about differences (related to better outcomes); and MI-Inconsistent therapist behavior (associated with poor outcomes). Dewi (2014) found the influence of home room program technical group guidance services as evidenced from the results of the resilience questionnaire which showed an increase in the results of the pretest to posttest on the total resilience score.

\section{METHOD}

This research was a quantitative. The selection of quantitative approaches is used to find out which MI techniques most effective increased the resilience. This research uses approach used is a quantitative approach and the type of Quasi Experimental. This study has two variables, namely the independent variable $(\mathrm{X})$, the $\mathrm{MI}$ technique. The dependent variable was resilience. Data collection techniques used in this study. Dissemination of resilience instruments is done to students, and the teacher observes resilience. The method of data analysis uses descriptive statistics and inferential statistics. The data analysis technique was performed by means of the average difference test. First the data normality test is done using Shapiro Wilk. If the data is normally distributed, the average difference test uses parametric test in the form of paired sample t-test (Santoso, 2004: 56). However, if the data are not normally distributed, the average difference test uses a non-parametric test in the form of the Wilcoxon Signed Ranks Test.

\section{RESULT}

Testing research showed there increase at resilience is done by testing the Paired Sample test for the sample group and Independent t-test sample in experimental as shown in the following Table 1 .

\begin{tabular}{|c|c|c|c|c|}
\hline & Aspec & $\mathrm{t}$ value & $P$ value & Result \\
\hline Pair 1 & $\begin{array}{c}\text { PRE-TEST - } \\
\text { Post }\end{array}$ & 8,720 & 0,000 & Significant \\
\hline
\end{tabular}

The Effectiveness of Motivational Interviewing in increasing Resilience Students who are victims of sexual violence are tested through paired t-tests or paired t-tests. Previously conducted paired t test for each pre-test and post-test results for each group. If $t$ arithmetic is greater than $\mathrm{t}$ table then the technique used is effective in increasing certain aspects in certain groups at $\alpha=0.05$ The significance value of $t$ arithmetic from the pre-test results of the experimental group shows a significant difference between the results of pre-test and post-test with comparing the significance of $\mathrm{t}$ arithmetic of $0,000<0.005$.

The results of MI could increase resilience of students who are victims of sexual violence mean that there is a difference in the tendency of being more resilient before using the Motivational Interviewing technique and after the Motivational Interviewing technique. If the significance of $t$ arithmetic $<0.05$ then the treatment is effective. Based on the results of tests on the experimental group proved that Motivational Interviewing techniques are effective increased for resilience. While the results of the $\mathrm{N}$-Gain test are explained in Table 2 below.

\begin{tabular}{|c|c|c|c|c|}
\hline Group & $\mathrm{N}$ & Mean & $\begin{array}{c}\text { Std. } \\
\text { Deviation }\end{array}$ & Std. Error Mean \\
\hline gain Experiment & 10 & 0,4299 & 0,17397 & 0,03231 \\
Control & 10 & 0,0092 & 0,04952 & 0,00920 \\
\hline
\end{tabular}

Table 2:- Descriptive N-Gain Results between Pre-Test and Post-Test in the Experiment Group

Source: Data processed

The results of the N-Gain test showed the experimental group with an average $\mathrm{N}$-gain of 0.4299 greater than the average $\mathrm{N}$-gain of the control group of 0.0092 . This reinforces that the Motivational Interviewing technique is effective to increase resilience. 


\section{DISCUSSION}

The Motivational Interviewing technique was chosen to increase resilience is related to the functions of understanding, prevention and alleviation, individuals learning and practicing content in the form of values, perceptions, affections, attitudes, actions and habits that are relating to the personal and social life of adolescents can be needed to increase resilience. Then, the Motivational Interviewing technique is used on the grounds that this technique facilitates students of victims of sexual violence so they can practice empathizing, understand themselves from other perspectives, get support from others, get new concepts from the roles played, gain new experiences, engage in groups and see how other people behave effectively.

By using this technique it is expected that students can experience firsthand about the attitudes, habits, values and skills needed to increase their resilience. The $t$ paired sample calculation, the results are significant, namely there is a significant difference between resilience before and after getting Motivational Interviewing techniques, so that $\mathrm{Ha}$ is accepted and Ho is rejected, thus showing an increase in students' resilience of victims of sexual violence between before and after being given Motivational Interviewing techniques. Therefore the hypothesis proposed in this study was accepted. This means that the resilience of students who are victims of sexual violence can be improved by Motivational Interviewing techniques.

Motivational interviewing with four stages of auditory and visual stimulation, guided by nurses can change perceptions in the prefrontal cortex so that changes in meaning of life and changes in positive perception, after positive perceptions appear, the nervous system is activated, causing changes in the hypothalamus and pituitary. The end result of this change in perception is the acceleration of client adaptation and spiritual intelligence in the form of gratitude, patience, sincerity and increased resilience. The advantage of $\mathrm{MI}$ intervention is that it is easy to implement it, which can be easily applied by BK teachers in an effort to fulfill students' basic needs in terms of psychological and spiritual aspects.

Based on the explanation, it is concluded that the use of Motivational Interviewing techniques is very influential increased resilience. Although this research has been carried out as well as possible, but this study still has limitations including the implementation of research outside of school hours that is after school. The condition of students who are victims of sexual violence who have experienced fatigue makes the researcher must be able to make students victims of sexual violence spirit follow the implementation of the study.

\section{CONCLUSION}

The effectiveness of motivational interviening techniques in increasing the resilience of victims of junior high school sexual violence in Nganjuk. Significant improvement was seen from the paired sample $t$ test results so the hypothesis was accepted. Also supported by the results of the $\mathrm{N}$-gain test which states that motivational interviening techniques are effective for resileince.

\section{RECOMMENDATION}

This conclutions some suggestions can be made as follows: 1) Guidance and Counseling teachers can utilize content mastering services with motivational interviening techniques to increase student resilience and should monitor the development of student resilience victims of sexual violence while at school; 2) The principal should give free time to the Guidance and Counseling teacher to be able to carry out Guidance and Counseling services outside of school hours. This was done to further enhance the competence of BK teachers in conducting counseling in schools.

\section{REFERENCES}

[1]. Apocada TR, Longabaugh R. 2009. Mechanisms of Change in Motivational Interviewing: a review and pleminary evaluation of evidence. Addiction 2009

[2]. Bonanno, G,A. 2004,Loss, Trauma and Human Resilience. Have We Underetimeted the Human Capacity ro thrive after aversive Evebnts?The American Psychological Association 59 91), 20-28

[3]. Connor, K. M., \& Davidson, J. R.T.2003. Development of a New Resilience Scale: The ConnorDavidson Resilience Scale (Cd-Risc). Depression and Anxiety

[4]. Dunn C, Deroo L, Rivara F.2001. The use of brief interventions adapted from Motivational interviewing across behavioral domains: a systematic review. Addiction. 96: 1725-1742. 10.1046/j.13600443.2001.961217253.x.

[5]. Erford, B. T. 2017. 40 Teknik Yang Harus Diketahui Setiap Konselor. Yogyakarta: Pustaka Pelajar

[6]. Hettema J, Steele J, Miller WR: 2005. Motivational interviewing. Annual Review of Clinical Psychology. 2005, 1: 91-111. 10.1146/annurev.clinpsy.

[7]. Grotberg, E. H. 1995. A guide to promoting resiliency in children: Strengthening the human spirit. Early Chidhood Development: Practice And Reflections, 8.

[8]. Miller W, Rollnick S.2012. Ten things that Motivational interviewing is not. Behavioural dan Cognitive Psychotherapy. 37: 129-140. 10.1017/S1352465809005128.

[9]. Miller W. 2005. Motivational interviewing: Research, practice, and puzzles. Addictive Behaviors. 21: 835842. 10.1016/0306-4603(96)00044-5 
[10]. Peters, R.D, Leadbeater, Bonnie, dan McMahon, Robbert J. 2005. Resilience in Children, Families, and Communities Linking Context to Practice and Policy. New York: Kluwer Academic / Plenum Publishers

[11]. Reivich K dan Shatte, A. 2002. The Resilience factor: 7 essential skill's for overcoming life's inevitable obstacles. New York : Random House inc.

[12]. Resnick B, Gwyther P, dan Roberto A. 2011. Resilience In Aging : Concepts, Research, and Outcomes. New York :Springer

[13]. Rollnick S, Miller W, Butler C.2012.Motivational interviewing in Health Care: Helping Patients Change Behavior. Guilford PublicationsGoogle Scholar

[14]. Santoso.S. 2004 .SPSS Statistik Multivariat. Jakarta: PT. Elex Media. Komputindo.

[15]. Soderlund, L. L. 2010. Motivational Interviewing in Theory and Practice. Swedia: UniTryck, Linköping, Swedia

[16]. Tugade, M. M. dan Fredrickson, B. L. 2004. Resilient Individuals Use Positive Emotions To Bounce Back From Negative Emotional Experiences. Journal of Personality and Social Psychology, 86, 320 - 333.

[17]. Wagner, Christopher C and Ingersoll, Karen S. 2008. Motivational Interviewing in Groups. Virginia Commonwealth University

[18]. Christopher C. Wagner dan Brian T. McMahon.2004. Motivational Interviewing and Rehabilitation Counseling Practice. Rehabilitation Counseling Bulletin 47(3):152-161 · April 